Potravinarstvo Slovak Journal of Food Sciences

vol. 14, 2020, p. 595-601

https://doi.org/10.5219/1380

Received: 5 May 2020. Accepted: 16 June 2020.

Available online: 28 August 2020 at www.potravinarstvo.com

(C) 2020 Potravinarstvo Slovak Journal of Food Sciences, License: CC BY 3.0

ISSN 1337-0960 (online)

\title{
ADAPTATION OF TWO-DIMENSIONAL ELECTROPHORESIS FOR MUSCLE TISSUE ANALYSIS
}

\author{
Anastasiya Akhremko, Ekaterina Vasilevskaya, Liliya Fedulova
}

\begin{abstract}
It is important to understand the molecular mechanisms that take place in muscle tissues and to predict meat quality characteristics. One of the most popular methods is two-dimensional electrophoresis, which allows us to visualize, share and identify different molecules, including meat proteins. However, the standard conditions of this method are not universal for all types of raw material, so the authors suggest a new variation of two-dimensional electrophoresis for muscle tissue analysis. Samples were tested by the classical version of isoelectric focusing (cathode buffer in the top and anode buffer in the bottom chamber of the electrophoresis cell) and its variation (anode buffer in the top and cathode buffer in the bottom chamber of the electrophoresis cell). Next, extruded gels were incubated in two different buffer systems: the first was equilibration buffer I ( $6 \mathrm{M}$ urea, $20 \% \mathrm{w} / \mathrm{v}$ glycerol, $2 \% \mathrm{w} / \mathrm{v}$ SDS and 1\% w/v Ditiothreitol in $375 \mathrm{mM}$ Tris-HCl buffer, $\mathrm{pH} 8.8$ ) followed by equilibration buffer II ( $6 \mathrm{M}$ urea, $20 \% \mathrm{w} / \mathrm{v}$ glycerol, $2 \% \mathrm{w} / \mathrm{v}$ SDS and $4 \% \mathrm{w} / \mathrm{v}$ iodoacetamide in $375 \mathrm{mM}$ Tris- $\mathrm{HCl}$ buffer $\mathrm{pH} 8.8$ and the second, buffer A, consisting of $5 \mathrm{M}$ urea, $2 \% \mathrm{w} / \mathrm{v} \mathrm{SDS}, 5 \% \mathrm{v} / \mathrm{v}$ mercaptoethanol, $62.5 \mathrm{mM}$ Tris-HCl buffer, $\mathrm{pH} 6.8$ and $0.01 \% \mathrm{w} / \mathrm{v}$ bromophenol blue. Electrophoretic studies of muscle tissue revealed the best protein separation after changing the direction of the current (authors' variation), while no differences were detected after changing incubation buffers.
\end{abstract}

Keywords: two-dimensional electrophoresis; muscle protein; isoelectric focusing; meat

\section{INTRODUCTION}

Meat and meat products will always play an important role in the human diet as a source of high-grade protein. There is a wide variety of meat processing products, the range of which is regularly updated. Depending on the processing technology, meat proteins undergo extensive modifications that affect their quality, shelf life, nutritional properties, and health effects. At the same time, tenderness and juiciness are the criteria most judged by consumers (Cao et al., 2020; Hollung et al., 2007).

These criteria are influenced by the following factors: genetics, environment, animal welfare, and further processing. The molecular mechanisms underlying such processes are still of interest. However, genetic information remains static throughout the life of the body, while the protein composition is dynamic and changes depending on factors affecting protein synthesis or degradation (Peng and Gygi, 2001). Thus, proteomics analysis makes it possible to better understand the molecular mechanisms that occur in tissues and to predict the most important characteristics, particularly in the case of meat (Bendixen, 2005; Bendixen et al., 2005; Zamaratskaia and $\mathrm{Li}$, 2017).
Proteomic methods over the past decade have found increasing application in various fields of science and agriculture. To date, proteomic tools have improved significantly, and mass spectrometric methods are being developed very rapidly. Most proteomic methods are based on the separation of proteins in at least two directions, using chromatographic or electrophoretic methods, with further identification using mass spectrometry methods (Soares et al., 2012; Suman et al., 2014). In this paper, attention is focused on the method of two-dimensional gel electrophoresis (2-DE), because it is still an excellent way to visualize protein components and widely used in meat science, with an emphasis on sample preparation and aspects of isoelectric focusing (IEF).

Traditionally, 2-DE is carried out by fractionation of proteins according to two different physicochemical parameters. In the first direction, proteins are separated by charge according to their isoelectric point with IEF, and then in the second direction by their molecular weight with polyacrylamide gel electrophoresis (PAAG). Some variations of conducting 2-DE are discussed below to identify the most optimal variant for analysis of the meat proteome. 


\section{Scientific hypothesis}

The classical variation of two-dimensional electrophoresis does not fully reveal muscle tissue proteins. It is necessary to select optimal conditions for the analysis. Changing the IEF parameters and additional incubation in lysis buffers will increase the resolution of the 2-DE method for muscle proteins.

\section{MATERIAL AND METHODOLOGY}

\section{Materials}

Chemical reagent: Urea, Thiourea, Ditiothreitol, Sodium hydroxide (NaOH), Glycerol, Sodium dodecyl sulfate (SDS), Tris, Acrylamide, Ammonium persulfate (APS), 2-Propanol, Acetic acid (PanReac, Spain); Bis-acrylamide, Tetramethylethylenediamine (TEMED), Mercaptoethanol, Bromophenol blue, Glycine, Coomassie Brilliant Blue G-250, Triton X-100 (Helicon Russia); Ampholyte (Serva, Germany) and Phosphoric (V) acid $\left(\mathrm{H}_{3} \mathrm{PO}_{4}\right)$ (Componentreaktiv, Russia).

The object of the study was the Vietnamese Pot-bellied from healthy females of $60-65$ days old pig $L$. dorsi muscle. Samples were taken within 20 minutes after slaughter and placed in dry ice. Frozen muscle tissues $(50 \mathrm{mg}$ ) were homogenized in $1 \mathrm{~mL} 7 \mathrm{M}$ Urea, $2 \mathrm{M}$ Thiourea, $1 \%$ Ditiothreitol, $0.4 \%$ Triton X-100, $2 \% \mathrm{pH}$ 3-10 Ampholyte. Homogenates were centrifugated with an acceleration of $20000 \mathrm{~g}$ for 20 minutes. Three samples, obtained from different animals, were studied by twodimensional electrophoresis in two variations of isoelectric focusing (IEF) and two methods of gel incubation after IEF. Figure 1 shows the experimental design.

\section{Two-dimensional gel electrophoresis (2-DE)}

IEF in the first dimension was performed at $3650 \mathrm{~V} \cdot \mathrm{h}^{-1}$. The anodic and cathodic electrode solutions used for IEF were $0.01 \mathrm{M}$ Phosphoric $(\mathrm{V})$ acid and $0.02 \mathrm{M}$ Sodium hydroxide, respectively, in $2.4 \mathrm{~mm} \times 160 \mathrm{~mm}$ tube gels.

In the first classical version of IEF, the cathode buffer ( $0.02 \mathrm{M}$ sodium hydroxide) was in the upper chamber of the electrophoresis cell, and the anode buffer $(0.01 \mathrm{M}$ orthophosphoric acid) was in the lower one. In the second variation of IEF, the electric current direction was changed: the anode buffer was in the upper chamber, and the cathode buffer was in the lower one.

After the IEF, gels were incubated in two different ways: extruded tube gels were incubated for $10 \mathrm{~min}$, in $2.5 \mathrm{~mL}$ of equilibration buffer I (6 M urea, 20\% w/v glycerol, $2 \% \mathrm{w} / \mathrm{v}$ SDS and $1 \% \mathrm{w} / \mathrm{v}$ Ditiothreitol in $375 \mathrm{mM}$ Tris$\mathrm{HCl}$ buffer, $\mathrm{pH} 8.8$ ), followed by equilibration buffer II (6 M urea, 20\% w/v glycerol, 2\% w/v SDS and $4 \% \mathrm{w} / \mathrm{v}$ iodoacetamide in $375 \mathrm{mM}$ Tris- $\mathrm{HCl}$ buffer, $\mathrm{pH} 8.8$ ); extruded tube gels were incubated for $10-15 \mathrm{~min}$, in $2.5 \mathrm{~mL}$ buffer A $(5 \mathrm{M}$ urea, $2 \% \mathrm{w} / \mathrm{v}$ SDS, $5 \% \mathrm{v} / \mathrm{v}$ mercaptoethanol, $62.5 \mathrm{mM}$ Tris-HCl buffer, $\mathrm{pH} 6.8$ and $0.01 \% \mathrm{w} / \mathrm{v}$ Bromophenol blue).

For SDS-PAGE $(12 \% \mathrm{~T}, 2.6 \% \mathrm{C})$ equilibrated tube gels were transferred to a $12.5 \%$ polyacrylamide gel $(170 \mathrm{~mm} \times$ $180 \mathrm{~mm} \times 1.5 \mathrm{~mm}$ ). Electrophoresis was carried out with a gel running buffer containing $25 \mathrm{mM}$ Tris-HCl, $192 \mathrm{mM}$ glycine and $0.1 \% \mathrm{w} / \mathrm{v}$ SDS at $30 \mathrm{~mA}$ per gel until the bromophenol blue front had reached the lower edge of the gel. Experimental molecular weights were detected relatively to marker proteins $-250 ; 150 ; 100 ; 70 ; 50 ; 40$; 30; 20; 15; 10; $5 \mathrm{kDa}$ (Thermo Scientific, Lithuania).

\section{Protein visualization and image analysis}

Protein spots were visualized staining by solution Coomassie $(0.05 \% \mathrm{w} / \mathrm{v}$ Coomassie Brilliant Blue G-250, $10 \% \mathrm{v} / \mathrm{v}$ Acetic acid and 25\% v/v 2-Propanol) for 1 hour. The destaining procedure was carried out by incubating in $10 \% \mathrm{v} / \mathrm{v}$ Acetic acid for 15 minutes several times until the background of the gel became transparent.

For computerized densitometry, two-dimensional electropherograms were used in a wet state. Their full digital images and/or images of individual fragments were obtained using a Bio-5000 plus scanner (Serva, Germany). Scanned images were analyzed with ImageMasterTM $2 \mathrm{D}$ Platinum software powered by Melanie 8.0 (GE Healthcare and Genebio, Switzerland). Spots were detected and quantified automatically with minimum thresholds: saliency -11 , min area -5 and smooth -3 . The relative optical density (OD) and relative volume were computed to correct for differences in gel staining. These measures take into account variations due to protein loading and staining, by considering the total OD or volume over all the spots in the gel. The digitized 2DE images of the cortex were then compared by the matching method (Grove et al., 2006).

Protein spots on muscle tissue two-dimensional electropherograms were interpreted following the SwissProt database (O'Donovan et al., 2002) and the Muscle organ proteomics database (Kovaleva et al., 2013).

\section{Statistical analysis}

The experimental data were analyzed using ordinary oneway ANOVA (between gels, obtained with different variation IEF) by ImageMaster ${ }^{\mathrm{TM}}$ 2D Platinum software powered by Melanie 8.0 (GE Healthcare and Genebio, Switzerland).

A $p$ value $<0.05$ was considered to indicate a significant difference. All results are presented as mean \pm SD from at least three independent experiments.

\section{RESULTS AND DISCUSSION}

In most scientific works, IEF is performed using a thin layer of gel deposited on a plastic substrate (IPG Dry Strip) to speed up and simplify the process. (Naveena et al., 2017; Di Luca et al., 2016; Lee, Saraygord-Afshari and Low, 2020). However, the glass-tube IEF, despite process complexity, has an advantage in the resolution and protein loading volume in the gel (Matsumoto et al., 2019). Based on foregoing, for this experiment, we selected glass-tube IEF.

In accordance with the experimental design, depicted in Figure 1, four 2-DE variations were performed; the obtained electropherograms are presented in Figure 2.

A different distribution of pig muscle protein was noted for molecular weights (MW) and isoelectric points (pI). 


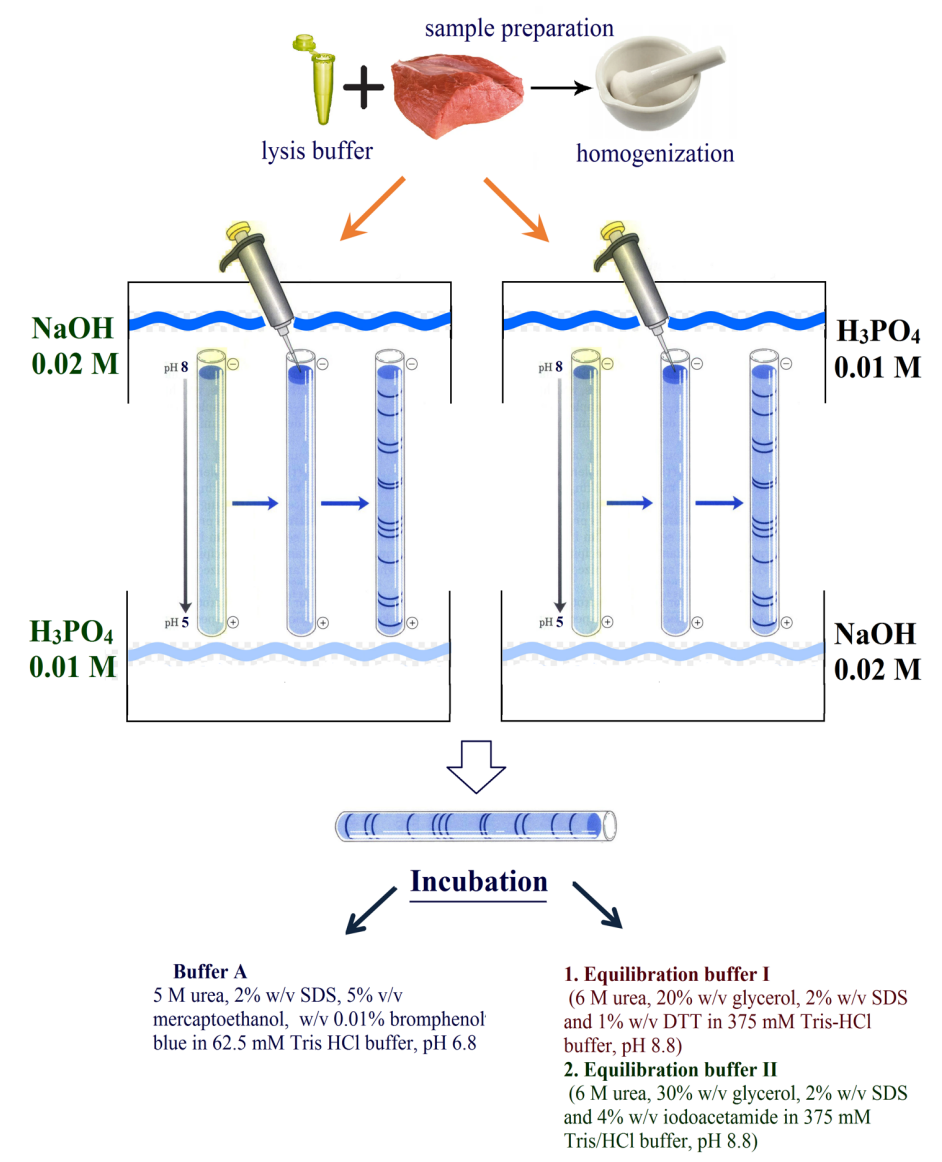

Figure 1 Experimental design of pig L. dorsi 2-DE.

Table 1 Results of the densitometry analysis.

\begin{tabular}{|c|c|c|c|c|}
\hline \multirow[b]{2}{*}{ № Spot } & \multicolumn{4}{|l|}{ Name of gel } \\
\hline & $\begin{array}{l}\text { A } \\
(\text { vol } \pm \text { SD })\end{array}$ & $\begin{array}{l}\text { B } \\
(\operatorname{vol} \pm \mathrm{SD})\end{array}$ & $\begin{array}{l}\text { C } \\
(\text { vol } \pm \text { SD })\end{array}$ & $\begin{array}{l}\text { D } \\
(\text { vol } \pm \text { SD })\end{array}$ \\
\hline 1 & $8.19 \pm 1.1622 \times 10^{7}$ & $5.75 \pm 0.90 \times 10^{7}$ & $7.47 \pm 0.06 \times 10^{7}$ & $7.34 \pm 0.10 \times 10^{7}$ \\
\hline 2 & $10.18 \pm 0.2622 \times 10^{7}$ & $10.70 \pm 0.14 \times 10^{7}$ & $11.48 \pm 0.26 \times 10^{7}$ & $12.00 \pm 0.34 \times 10^{7}$ \\
\hline 3 & $9.37 \pm 0.2022 \times 10^{7}$ & $8.97 \pm 0.44 \times 10^{7}$ & $8.58 \pm 0.53 \times 10^{7}$ & $9.64 \pm 0.63 \times 10^{7}$ \\
\hline 4 & $4.39 \pm 0.2522 \times 10^{7}$ & $9.47 \pm .1 .05 \times 10^{7}$ & $7.51 \pm 0.15 \times 10^{7}$ & $7.20 \pm 0.23 \times 10^{7}$ \\
\hline 5 & $1.92 \pm 0.39 \times 10^{7}$ & $2.71 \pm 0.72 \times 10^{7}$ & $2.95 \pm 0.54 \times 10^{7}$ & $4.03 \pm 0.66 \times 10^{7}$ \\
\hline 6 & $10.65 \pm 0.62 \times 10^{7}$ & $9.42 \pm 0.84 \times 10^{7}$ & $14.42 \pm 0.60 \times 10^{7}$ & $13.23 \pm 0.98 \times 10^{7}$ \\
\hline 7 & $8.19 \pm 0.41 \times 10^{7}$ & $5.75 \pm 1.22 \times 10^{7}$ & $7.47 \pm 0.07 \times 10^{7}$ & $7.34 \pm 0.64 \times 10^{7}$ \\
\hline 8* & $0.64 \pm 0.16 \times 10^{7}$ & $1.04 \pm 0.88 \times 10^{7}$ & $13.30 \pm 0.50 \times 10^{7}$ & $11.82 \pm 0.97 \times 10^{7}$ \\
\hline 9* & $0.34 \pm 0.05 \times 10^{7}$ & $0.42 \pm 0.14 \times 10^{7}$ & $6.35 \pm 0.60 \times 10^{7}$ & $6.23 \pm 0.74 \times 10^{7}$ \\
\hline $10 *$ & $2.42 \pm 0.61 \times 10^{7}$ & $1.26 \pm 0.58 \times 10^{7}$ & $5.84 \pm 0.64 \times 10^{7}$ & $4.63 \pm 0.43 \times 10^{7}$ \\
\hline $11 *$ & $1.24 \pm 0.02 \times 10^{7}$ & $1.57 \pm 0.27 \times 10^{7}$ & $10.68 \pm 0.74 \times 10^{7}$ & $9.68 \pm 0.85 \times 10^{7}$ \\
\hline $12 *$ & $0.40 \pm 0.25 \times 10^{7}$ & $0.89 \pm 0.31 \times 10^{7}$ & $13.37 \pm 1.20 \times 10^{7}$ & $10.78 \pm 0.92 \times 10^{7}$ \\
\hline $13 *$ & $0.29 \pm 0.08 \times 10^{7}$ & $0.45 \pm 0.11 \times 10^{7}$ & $4.91 \pm 0.27 \times 10^{7}$ & $5.45 \pm 0.59 \times 10^{7}$ \\
\hline $14 *$ & $0.24 \pm 0.04 \times 10^{7}$ & $0.13 \pm 0.02 \times 10^{7}$ & $3.16 \pm 0.54 \times 10^{7}$ & $3.19 \pm 0.71 \times 10^{7}$ \\
\hline $15 *$ & $4.23 \pm 0.25 \times 10^{7}$ & $0.24 \pm 0.08 \times 10^{7}$ & $5.61 \pm 0.44 \times 10^{7}$ & $2.47 \pm 0.37 \times 10^{7}$ \\
\hline
\end{tabular}

Note: Spot $\mathrm{Vol}^{* *}$ were normalized by total valid spot volume and mean of value from duplicate analytical gels from three replicates. Data represented are means $\pm \mathrm{SD}$ of three independent experiments. *Significant differences were found between IEF variations in the distribution of values between gels within the same sample with $p<0.05$. **Vol: The volume of a spot is the sum of the background-subtracted gray values of all pixels delimited by the spot border. By default, the background is defined as the minimum gray value on the spot border. 

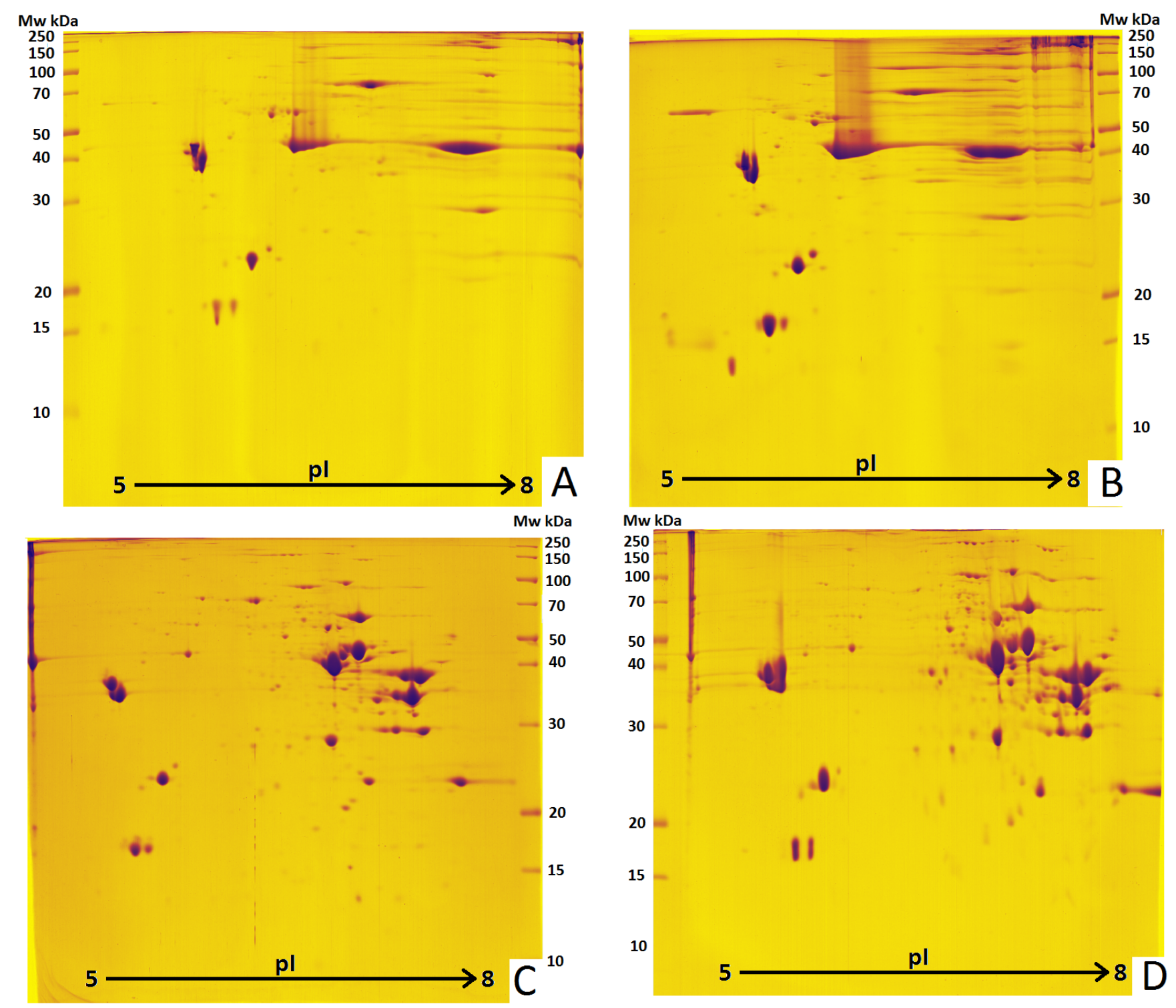

Figure 2 2-DE of pig L. dorsi. Note: A - $0.02 \mathrm{M} \mathrm{NaOH}$ were from above, $0.01 \mathrm{M} \mathrm{H}_{3} \mathrm{PO}_{4}$ from below, tube gels were incubated in equilibration buffer I. and II; $\mathrm{B}-0.02 \mathrm{M} \mathrm{NaOH}$ were from above, $0.01 \mathrm{M} \mathrm{H}_{3} \mathrm{PO}_{4}$ from below, tube gels were incubated in buffer $\mathrm{A} ; \mathrm{C}-0.01 \mathrm{M} \mathrm{H}_{3} \mathrm{PO}_{4}$ were from above, $0.02 \mathrm{M} \mathrm{NaOH}$ were from below, tube gels were incubated in equilibration buffer I and II; D - $0.01 \mathrm{M} \mathrm{H3PO4} \mathrm{were} \mathrm{from} \mathrm{above,} 0.02 \mathrm{M} \mathrm{NaOH}$ were from below, tube gels were incubated in buffer A.

In the classical version of IEF (O'Farrell, 1975; Hirano, 1982; Kimura et al., 2003), when $0.02 \mathrm{M} \mathrm{NaOH}$ is in the upper chamber of the electrophoretic cell (Figure 2A), good protein separation is observed within a pI range of 5 to 6.5 , such as tropomyosin beta chain (Mw $33.5 \mathrm{kDa}$, pI 4.80) (D'Alessandro et al., 2011; Peng et al., 2013), tropomyosin alpha-3 chain (Mw $33.5 \mathrm{kDa}, \mathrm{pI} 4.71$ ) (Davoli et al., 2000), myosin light chain 3-like (Mw $22.0 \mathrm{kDa}, \mathrm{pI} 5.24)$ and myosin light chain $1 / 31(\mathrm{Mw}$ 21.0 kDa, pI 5.80) (Montowska and Pospiech, 2012; Kovaleva et al., 2013).

Moreover, on two-dimensional electropherograms with incubation in buffer A (Figure 2B), these proteins are most clearly identified (Ros et al., 2002; Montowska and Pospiech, 2007; Paredi, Mori and Mozzarelli, 2018). At the same time, in the alkaline zone of the gel, a blurred image of protein fractions is observed. A completely different gel was obtained when the current direction changed during the IEF, when $0.01 \mathrm{M}$ orthophosphoric acid was in the upper chamber of the electrophoretic cell. Clear and well-defined protein spots were obtained with uniform distribution over the entire gel area (Chernukha et al., 2017). Presumably, this was because proteins with acidic and neutral pI are more highly represented in muscle tissue, resulting in a higher proportion of positively charged proteins. Since the current always goes in the direction from "plus" to "minus", when changing the direction of the current flow, it is easier for positively charged proteins, which are always layered on top to move to the lower chamber of the electrophoretic cell, where a negative charge (cathode) is created (Colangeli et al., 2018). 


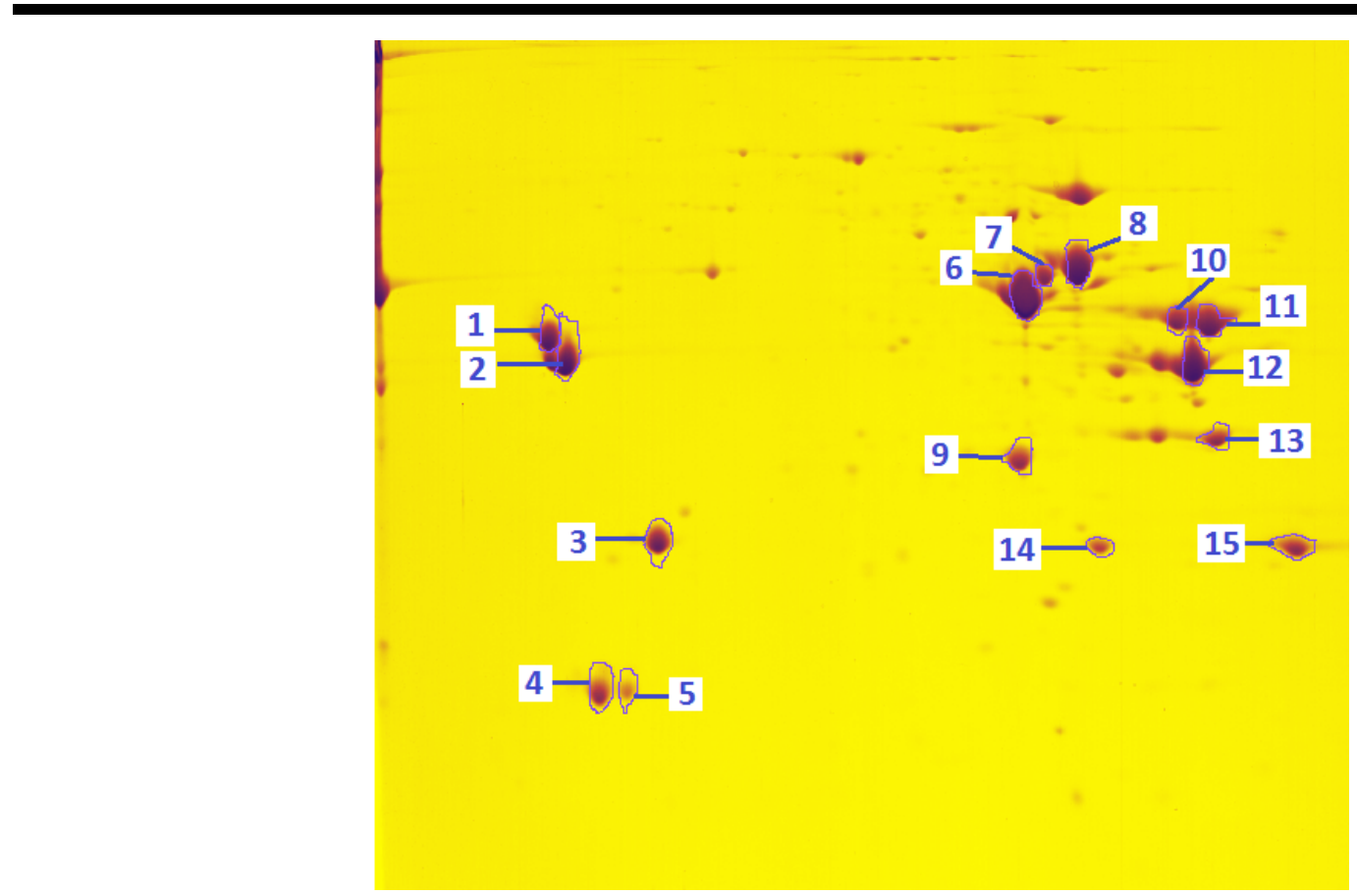

Figure 32 -DE of pig $L$. dorsi with the designation of structural muscle proteins for densitometric assessment.

Interestingly, during incubation in equilibration buffer I and II (Figure 2C), protein spots with a molecular weight greater than $50 \mathrm{kDa}$ were better visualized (Vasilevskaya and Akhremko, 2019). In contrast, when incubated in buffer A (Figure 2D), protein spots with a molecular mass of less than $40 \mathrm{kDa}$ were better visualized. The latter variation was used in a study by Kovalev (Kovalyov et al., 2006; Zvereva et al., 2015), and analysis of the results found that this method, as in the case of incubation in equilibration buffers, allows the best detection of muscle tissue proteins.

Major structural proteins of pig muscle tissue (Figure 3) were found (Montowska and Pospiech, 2012) and subjected to densitometric analysis (Table 1). The Fold change index (Persike et al., 2018) was calculated. Fold change index is the ratio between the volume of protein spots with the highest average value and the lowest average value. Eight fractions were detected $(\geq 2$-fold change, $p<0.05$ ) with increased spot volume by at least 2 times compared with the classical version of the IEF (marked $*$ in Table 1 ).

Thus, the variation of the IEF, when sodium hydroxide is in the upper chamber of the electrophoresis cell, has a lower resolution and does not properly detect protein fractions in the alkaline zone. So, in Figures $2 \mathrm{~A}$ and $2 \mathrm{~B}$, proteins in the right half of the gel are noticeably out of focus. It is necessary to increase the number of volt-hours by at least $40 \%$ (up to $7-8$ hours) for better protein separation in this area.

After changing the direction of electric current during the IEF, the process takes 4 hours. As a result, at least two times more protein spots are detected on 2-DE, including major structural muscle proteins, such as glyceraldehyde3-phosphate dehydrogenase (Han et al., 2019), troponins group (Mora et al., 2016; Drousiotis et al., 2020), 3-hydroxyacyl-Coenzyme A dehydrogenase, beta-enolase and others (Nolan et al., 2019).

\section{CONCLUSION}

The results of electrophoretic studies showed that the best option for the separation of meat proteins is to change the direction of the current. Thus, when the anode buffer (0.01 M orthophosphoric acid) is in the upper chamber of the electrophoretic cell, and the cathode buffer $(0.02 \mathrm{M}$ sodium hydroxide) is in the lower one, the most informative picture is obtained. Incubation in both buffer A and equilibration buffers can also be used.

Densitometric analysis showed that the use of new parameters allows us to identify a larger number of proteins (almost 2 times). An increase in the color intensity of certain fractions is also noted. Thus, the proposed variation of the IEF can be used as the main one for muscle proteins electrophoretic analysis, since it requires less time and has a higher resolution.

\section{REFERENCES}

Bendixen, E. 2005. The use of proteomics in meat science. Meat Science, vol. 71 , no. 1 , p. 138-149. https://doi.org/10.1016/j.meatsci.2005.03.013

Bendixen, E., Taylor, R., Hollung, K., Hildrum, K. I., Picard, B., Bouley, J. 2005. Proteomics, an approach towards understanding the biology of meat quality. Indicators of Milk and Beef Quality (ed. JF Hocquette and S Gigli), vol. 112, p. 81-94.

Cao, C., Xiao, Z., Ge, C., Wu, Y. 2020. Application and research progress of proteomics in chicken meat quality and identification: a review. Food Reviews International, 23 p. https://doi.org/10.1080/87559129.2020.1733594

Chernukha, I. M., Fedulova, L. V., Vasilevskaya, E. R., Kotenkova, E. A. 2017. Comparative study of biocorrective protein-peptide agent to improve quality and safety of livestock products. Potravinarstvo Slovak Journal of Food Sciences, vol. 11, no. 1, p. 539-543. https://doi.org/10.5219/590

Colangeli, M., Giardinà, C., Giberti, C., Vernia, C. 2018. Nonequilibrium two-dimensional Ising model with stationary uphill diffusion. Physical Review E, vol. 97, no. 3. https://doi.org/10.1103/PhysRevE.97.030103 
D'Alessandro, A., Marrocco, C., Zolla, V., D'Andrea, M., Zolla, L. 2011. Meat quality of the longissimus lumborum muscle of Casertana and Large White pigs: metabolomics and proteomics intertwined. Journal of Proteomics, vol. 75, no. 2, p. 610-627. https://doi.org/10.1016/j.jprot.2011.08.024

Davoli, R., Bigi, D., Fontanesi, L., Zambonelli, P., Yerle, M., Zijlstra, C., Bosma, A. A., Robic, A., Russo, V. 2000. Mapping of 14 expressed sequence tags (ESTs) from porcine skeletal muscle by somatic cell hybrid analysis. Animal Genetics, vol. 31, no. 6, p. 400-403. https://doi.org/10.1046/j.1365-2052.2000.00687.x

Di Luca, A., Hamill, R. M., Mullen, A. M., Slavov, N., Elia, G. 2016. Comparative Proteomic Profiling of Divergent Phenotypes for Water Holding Capacity across the Post Mortem Ageing Period in Porcine Muscle Exudate. PLOS ONE, vol. 11, no 3, p. e0150605. https://doi.org/10.1371/journal.pone.0150605

Drousiotis, K., Koutalianos, D., Baumann, C. G., Bullard, B. 2020. Tropomyosin as a Stretch Sensor in the Troponin Bridges of Insect Flight Muscle. Biophysical Journal, vol. 118, no. 3, p. 495a. https://doi.org/10.1016/j.bpj.2019.11.2738 Grove, H., Hollung, K., Uhlen, A. K., Martens, H., Faergestad, E. M. 2006. Challenges related to analysis of protein spot volumes from two-dimensional gel electrophoresis as revealed by replicate gels. Journal of Proteome Research, vol. 5, no. 12, p. 3399-3410. https://doi.org/10.1021/pr0603250

Han, X., Xiong, Y., Zhao, C., Xie, S., Li, C., Li, X., Liu, X., Li, K., Zhao, S., Ruan, J. 2019. Identification of Glyceraldehyde-3-Phosphate Dehydrogenase Gene as an Alternative Safe Harbor Locus in Pig Genome. Genes, vol. 10, no 9, 11 p. https://doi.org/10.3390/genes 10090660

Hirano, H. 1982. Varietal differences of leaf protein profiles in mulberry. Phytochemistry, vol. 21, no. 7, p. 1513-1518. https://doi.org/10.1016/S0031-9422(82)85008-5

Hollung, K., Veiseth, E., Jia, X., Færgestad, E. M., Hildrum, K. I. 2007. Application of proteomics to understand the molecular mechanisms behind meat quality. Meat Science, vol. 77, no. 1, p. 97-104. https://doi.org/10.1016/j.meatsci.2007.03.018

Kimura, Y., Saeki, Y., Yokosawa, H., Polevoda, B., Sherman, F., Hirano, H. 2003. N-Terminal modifications of the 19S regulatory particle subunits of the yeast proteasome. Archives of Biochemistry and Biophysics, vol. 409, no. 2, p. 341-348. https://doi.org/10.1016/S0003-9861(02)00639-2

Kovaleva, M., Kovalev, L., Lisitskaya, K., Eremina, L., Ivanov, A., Krakhmaleva, I., Sadykhov, E., Shishkin, S. 2013. Muscle organs proteomics: multy-level database. FEBS Journal, vol. 280, Special Issue: SI Supplement: 1, p. 488.

Kovalyov, L. I., Kovalyova, M. A., Kovalyov, P. L., Serebryakova, M. V., Moshkovskii, S. A., Shishkin, S. S. 2006. Polymorphism of delta3,5-delta2,4-dienoyl-coenzyme A isomerase (the $\mathrm{ECH} 1$ gene product protein) in human striated muscle tissue. Biochemistry (Moscow), vol. 71, no. 4, p. 448-453. https://doi.org/10.1134/S0006297906040146

Lee, P. Y., Saraygord-Afshari, N., Low, T. Y. 2020. The evolution of two-dimensional gel electrophoresis- from proteomics to emerging alternative applications. Journal of Chromatography A, vol. 1615, 41 p. https://doi.org/10.1016/j.chroma.2019.460763

Matsumoto, H., Haniu, H., Kurien, B. T., Komori, N. 2019. Two-Dimensional Gel Electrophoresis by Glass Tube-Based IEF and SDS-PAGE. In Kurien, B., Scofield, R. Electrophoretic Separation of Proteins. New York, NY : Humana Press, p. 107-113. https://doi.org/10.1007/978-14939-8793-1_11
Montowska, M., Pospiech, E. 2007. Species identification of meat by electrophoretic methods. Acta Scientiarum Polonorum Technologia Alimentaria, vol. 6, no. 1, p. 5-16.

Montowska, M., Pospiech, E. 2012. Myosin light chain isoforms retain their species-specific electrophoretic mobility after processing, which enables differentiation between six species: 2DE analysis of minced meat and meat products made from beef, pork and poultry. Proteomics, vol. 12, no. 18, p. 2879-2889. https://doi.org/10.1002/pmic. 201200043

Mora, L., Calvo, L., Escudero, E., Toldrá, F. 2016. Differences in pig genotypes influence the generation of peptides in dry-cured ham processing. Food Research International, vol. $\quad 86, \quad$ p. $74-82$. https://doi.org/10.1016/j.foodres.2016.04.023

Naveena, B. M., Jagadeesh, D. S., Kamuni, V., Muthukumar, M., Kulkarni, V. V., Kiran, M., Rapole, S. 2017. In-gel and OFFGEL-based proteomic approach for authentication of meat species from minced meat and meat products. Journal of the Science of Food and Agriculture, vol. 98, no. 3, p. 1188-1196. https://doi.org/10.1002/jsfa.8572

Nolan, A. N., Mead, R. J., Maker, G., Bringans, S., Chapman, B., Speers, S. J. 2019. Examination of the temporal variation of peptide content in decomposition fluid under controlled conditions using pigs as human substitutes. Forensic science international, vol. 298, p. 161-168. https://doi.org/10.1016/j.forsciint.2019.02.048

O'Donovan, C., Martin, M. J., Gattiker, A., Gasteiger, E., Bairoch, A., Apweiler, R. 2002. High-quality protein knowledge resource: SWISS-PROT and TrEMBL. Briefings in Bioinformatics, vol. 3, no. 3, p. 275-284. https://doi.org/10.1093/bib/3.3.275

O'Farrell, P. H. 1975. High resolution two-dimensional electrophoresis of proteins. Journal of Biological Chemistry, vol. 250, no 10, p. 4007-4021.

Paredi, G., Mori, F., Mozzarelli, A. 2018. Proteomics of Meat Products. In de Almeida, A., Eckersall, D., Miller, I. Proteomics in Domestic Animals: from Farm to Systems Biology. Cham, Switzerland : Springer, 485 p. ISBN 978-3319-69682-9. https://doi.org/10.1007/978-3-319-69682-9_15

Peng, J., Gygi, S. P. 2001. Proteomics: the move to mixtures. Journal of Mass Spectrometry, vol. 36, no. 10, p. 1083-1091. https://doi.org/10.1002/jms.229

Peng, Y., Chen, X., Zhang, H., Xu, Q., Hacker, T. A., Ge, Y. 2013. Top-down targeted proteomics for deep sequencing of tropomyosin isoforms. Journal of Proteome Research, vol. 12, no. 1, p. 187-198. https://doi.org/10.1021/pr301054n

Persike, D. S., Marques-Carneiro, J. E., de Lima Stein, M. L., Targas Yacubian, E. M., Centeno, R., Canzian, M., de Silva Fernandes, M. J. 2018. Altered Proteins in the Hippocampus of Patients with Mesial Temporal Lobe Epilepsy. Pharmaceuticals, vol. 11, no. 4, 17 p. https://doi.org/10.3390/ph11040095

Ros, A., Faupel, M., Mees, H., van Oostrum, J., Ferrigno, R., Reymond, F., Michel, P., Rossier, J. S., Girault, H. H. 2002. Protein purification by offgel electrophoresis. Proteomics, vol. 2, no. 2, p. 151-156. https://doi.org/10.1002/1615-9861(200202)2:2<151::AIDPROT151>3.0.CO;2-9

Soares, R., Franco, C., Pires, E., Ventosa, M., Palhinhas, R., Koci, K., de Almeida, A. M., Varela Coelho, A. 2012. Mass spectrometry and animal science: protein identification strategies and particularities of farm animal species. Journal of Proteomics, vol. 75, no. 14, p. 4190-4206. https://doi.org/10.1016/j.jprot.2012.04.009

Suman, S. P., Rentfrow, G., Nair, M. N., Joseph, P. 2014. 2013 EARLY CAREER ACHIEVEMENT AWARD- 
Proteomics of muscle-and species-specificity in meat color stability. Journal of Animal Science, vol. 92, no. 3, p. 875882. https://doi.org/10.2527/jas.2013-7277

Vasilevskaya, E. R., Akhremko, A. G. 2019. Proteomic study of pig's spleen. Potravinarstvo Slovak Journal of Food Sciences, vol. 13, no. 1, p. 314-317. https://doi.org/10.5219/1093

Zamaratskaia, G., Li, S. 2017. Proteomics in meat sciencecurrent status and future perspective. Theory and Practice of Meat Processing, vol. 2, no. 1, p. 18-26. https://doi.org/10.21323/2414-438X-2017-2-1-18-26

Zvereva, E. A., Kovalev, L. I., Ivanov, A. V., Kovaleva, M. A., Zherdev, A. V., Shishkin, S. S., Lisitsyn, A. B., Chernukha, I. M., Dzantiev, B. B. 2015. Enzyme immunoassay and proteomic characterization of troponin I as a marker of mammalian muscle compounds in raw meat and some meat products. Meat Science, vol. 105, p. 46-52. https://doi.org/10.1016/j.meatsci.2015.03.001

\section{Acknowledgments:}

This work was supported by a grant from the Russian Science Foundation No. 19-76-10034.

\section{Contact address:}

Anastasiya Akhremko, V. M. Gorbatov Federal Research Center for Food Systems of RAS, Experimental-clinical research laboratory of bioactive substances of animal origin, Talalikhina st., 26, 109316, Moscow, Russia, Tel.: $+79152379497$

E-mail: a.ahremko@,fncps.ru

ORCID: https://orcid.org/0000-0002-0211-8171

*Ekaterina Vasilevskaya, V. M. Gorbatov, Federal Research Center for Food Systems of RAS, Experimentalclinical research laboratory of bioactive substances of animal origin, Talalikhina st., 26, 109316, Moscow, Russia, Tel.: +79688223598,

E-mail: e.vasilevskaya@,fncps.ru

ORCID: https://orcid.org/0000-0002-4752-3939

Liliya Fedulova, V. M. Gorbatov Federal Research Center for Food Systems of RAS, Experimental-clinical research laboratory of bioactive substances of animal origin, Talalikhina st., 26, 109316, Moscow, Russia, Tel.: +74956769211,

E-mail: 1.fedulova@fncps.ru

ORCID: http://orcid.org/0000-0003-3573-930X

Corresponding author: * 